\title{
Some biological characteristics of the smooth blaasop puffer fish Lagocephalus inermis (Temminck and Schlegel, 1850), from south-eastern Arabian Sea
}

\author{
PURBALI SAHA* AND SUJITHA THOMAS \\ Mangalore Research Centre of ICAR-Central Marine Fisheries Research Institute, Hoige Bazaar, Mangaluru - 575001 \\ Karnataka, India \\ "Department of Biosciences, Mangalore University, Mangalagangothri, Mangaluru - 574 199, Karnataka, India \\ e-mail: sujitha.thomas@icar.gov.in
}

\begin{abstract}
Length-weight relationship (LWR), condition factor, sex ratio, gonadosomatic index (GSI) and hepatosomatic index (HSI) of the smooth blaasop puffer fish Lagocephalus inermis (Temminck and Schlegel, 1850), an emerging fishery resource along south-eastern Arabian Sea were studied from 1,722 samples collected during August 2017-May 2019 from Mangalore Fishing Harbour, Karnataka, India. LWR indicated negative allometric growth $\left[\mathrm{W}=0.034805 \mathrm{~L}^{2.76}\right.$ (males); $\mathrm{W}=0.033574 \mathrm{~L}^{2.78}$ (females), $\mathrm{W}=0.033979 \mathrm{~L}^{2.77}$ (pooled)] and significant difference was observed in the $b$ value of the fishes. Sex ratio was $1: 1.08$. The ratio was unusually high during post-monsoon and Chi-square test revealed that the monthly sex ratio did not vary significantly throughout the year except for December and January $(\mathrm{p}<0.01)$. Condition factor $(K)$ and relative condition factor $\left(K_{n}\right)$ also were not significantly different between sexes. Two peak spawning seasons were identified, NovemberFebruary and August. The GSI was highest in August (female $=8.08$ and male $=5.82$ ) and lowest in May (female $=$ 3.32 and male $=3.49$ ). The HSI value was found to be inversely related to GSI and was highest in May (5.21) and lowest in August (3.99). These parameters are essential pre-requisites for stock assessment and sustainable management of the fishery resource.
\end{abstract}

Keywords: Arabian sea, Condition factor, Gonado-somatic index (GSI), Lagocephalus inermis, Length-weight relationship, Spawning

\section{Introduction}

Puffer fishes (Family: Tetraodontidae) include 184 species under 27 genera (Matsuura, 2015). The smooth blaasop puffer fish Lagocephalus inermis (Temminck and Schlegel, 1850) is widely distributed along south-eastern Arabian Sea and mostly found in 10-200 m depth range. Since 2009, the resource has emerged as a major species of economic and ecological significance along the Karnataka coast, south-eastern Arabian Sea (Thomas et al., 2009; Saha et al., 2019).

Biometric studies and study of biological parameters are considered as a major input for biomass estimation and management of fishery resources (Zargar et al., 2012) and it is imperative to study the growth characteristics related to weight and length of fish (Beyer, 1987; Morato et al., 2001). It also helps to evaluate the comparative well-being and variations occurring in fish populaces (Bolger and Connolly, 1989). Length and weight relationships enable fisheries researchers to determine biomass of a population from length frequency distribution and ascertain the condition of the fish population (Anderson and Gutreuter, 1983; Dulcic and Kraljevic, 1996). It has been proved to be an invaluable tool to study the morphological aspects of populaces dwelling in different regions and their life history (Goncalves et al., 1997). The health of a fish and of the population as a whole is reflected by the condition of the fish (Welcomme, 2001). Koops et al. (2004), described fish condition as an indicator of the available energy to allocate towards various traits of life, for example, migration, growth and reproduction. Studies on the sex ratio and length-weight relationship provide basic information to assess the reproductive potential and to estimate the stock size of fish populations (Stratoudakis et al., 2006).

Gonado-somatic index (GSI) is related to reproduction and spawning of fish and is the ratio between the weight of the fish body and its gonad (Parameswaran et al., 1974). This ratio is significant in determining the spawning period of a fish as the size and weight of matured gonads swiftly increases just before spawning (Yeldan and Avsar, 2000). The GSI value is highest when the fish attains full maturity and the value significantly declines after spawning. Hepato-somatic index (HSI) on the other hand is related to the energy reserves in liver and metabolic activity (Lenhardt et al., 2009). HSI value increases when food is available abundantly and the general conditions 
of the aquatic environment are favourable for growth. HSI value is considered to be a good indicator of recent feeding activity of the fish (Tyler and Dunns, 1976). Both HSI and GSI provide indications about the developmental pattern of fishes.

Length-weight relationship (LWR) for the genus Lagocephalus has been reported by many researchers from India and abroad (Naik and Jalihal, 1998; Joshi, 2004; Simon and Mazlan, 2008; Başusta et al., 2013; Sirisha and Rao, 2013; Bilge et al., 2017; Padmavathi et al., 2017; Anju et al., 2019). Limited studies on the biology of L. inermis are available from India (Joshi, 2004; Padmavathi et al., 2017; Anju et al., 2019). However, there is not much information on the species from the Karnataka coast of the south-eastern Arabian Sea. The present study on the length-weight relationships, condition factor, sex ratio, spawning season, GSI and HSI of the smooth blaasop puffer fish L. inermis from south-eastern Arabian Sea will provide relevant information required to assess the population characteristics and biological performance of the species, which in turn will help fishery management for its sustainable exploitation in the region.

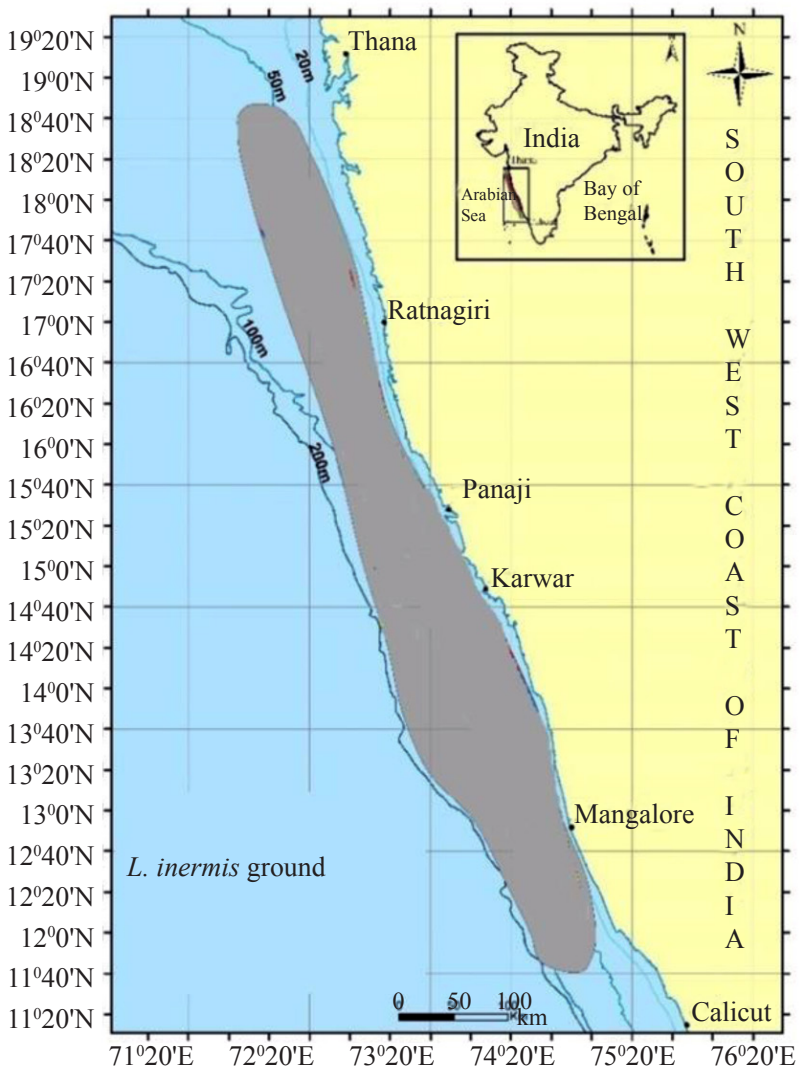

Fig. 1. Map showing the study area

\section{Materials and methods}

\section{Collection of samples}

Biweekly samples were collected from Mangalore Fishing Harbour during August 2017-May 2019. They were caught by multiday trawlers operating at a depth range of 10-200 $\mathrm{m}$ along south-eastern Arabian Sea $\left(11.969^{\circ} \mathrm{N} ; 71.794^{\circ} \mathrm{E}\right.$ to $\left.18.821^{\circ} \mathrm{N} ; 74.932^{\circ} \mathrm{E}\right)($ Fig. 1). A total of 1,722 specimens of L. inermis (Fig. 2) were collected and brought to the laboratory for analysis. Each fish was measured using a measuring board for total length (TL) up to the nearest $0.1 \mathrm{~cm}$ and an electronic balance for total weight (TW) up to the nearest $0.01 \mathrm{~g}$.

\section{Length-weight relationship}

To estimate length-weight relationships (LWR), the equation $\mathrm{W}=\mathrm{aL}^{\mathrm{b}}$, was used, where $\mathrm{W}$ is the total weight $(\mathrm{g}), \mathrm{L}$ is the total length $(\mathrm{cm}), a$ is the intercept and $b$ is the slope (Le Cren, 1951). The degree of association between the variables was computed by the determination coefficient, $\mathrm{r}^{2}$. Significance of the regression was assessed by analysis of variance (ANOVA) and the $b$-value for each species was tested by t-test to verify whether it differs significantly from the predictions for isometric growth $(b=3)$ (Pauly, 1993).

\section{Condition factor}

The Fulton's condition factor $(K)$, was estimated using the equation $K=100 * \mathrm{~W} / \mathrm{L}^{3}$, where W is the total weight of the fish and L is the total length (Ricker, 1975). Relative condition factor $\left(K_{n}\right)$, was calculated using the formula. $K_{n}=\mathrm{W}_{\mathrm{o}} / \mathrm{W}_{\mathrm{c}}$, where $\mathrm{W}_{\mathrm{o}}$ is the observed weight and $\mathrm{W}_{\mathrm{c}}$ is the estimated weight calculated from LWR (Vazzoler, 1996).

When the value of $K_{n} \geq 1$, the fish is in good condition and vice versa when the value of $K_{n}<1$. Weight of the

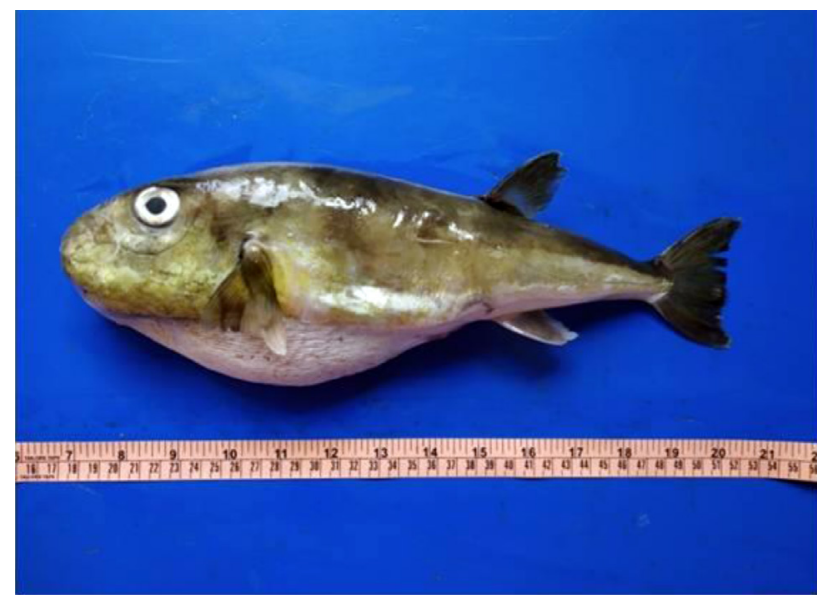

Fig. 2. L. inermis from south-eastern Arabian Sea 
fish is inclusive of the weight of the stomach. ANOVA was used to test the significance of the condition factor between months and between the sexes.

\section{Sex raio}

The sex ratio of males to females $(\mathrm{M}: \mathrm{F})$ was calculated as: total number of males/total number of females (Vazzoler, 1996). Chi-square $\left(\chi^{2}\right)$ test was used to verify significant differences between sex ratio of the species and commonly expected 1:1 sex ratio (Sokal and Jamesrohlf, 1987), using the formula:

$$
\chi^{2}=\frac{\Sigma(\mathrm{O}-\mathrm{E})^{2}}{\mathrm{E}}
$$

Spawning season

The classification of maturity stages is aimed to study the spawning period and to calculate the size/age at sexual maturity. The International Council for the Exploration of Sea (ICES) scales was used to recognise the different stages of the gonads (Lovern and Wood, 1937). The ovaries and testes were categorised into seven stages accordingly (I, II, III, IV, V, VI, VIIa, VIIb and IIb). Fresh ovaries and testes were examined macroscopically to study the general external characteristics. For ease of understanding the spawning period, stages I and II were combined and categorised as immature stage and from stage III to IIb, as mature stage.

Gondaosomatic index (GSI) and hepatosomatic index (HSI)

Sex of the sample was determined after dissection and weight of gonads was recorded using an electronic balance to the nearest $0.01 \mathrm{~g}$. The samples were wiped using blotting paper to remove excess moisture from the surface and then the measurements of the body, gonads and liver were recorded. The monthly change in gonadal development helped in understanding the spawning season of the species and was determined by seasonal fluctuations in GSI (Anderson and Gutreuter, 1983). The HSI was calculated using the formula given by Welcomme (2001):

$$
\text { HSI }=\frac{\text { Weight of liver }}{\text { Weight of body }} \quad \text { X } 100
$$

GSI of both male and female fishes was calculated using the formula (Welcomme, 2001):

\section{Results}

$$
\text { GSI }=\frac{\text { Weight of gonad }}{\text { Weight of body }} \times 100
$$

\section{Length frequency distribution}

A total of 1,568 samples were collected for analysing the length frequency distribution and length-weight relationships. The length frequency contributing to the fishery was found to be in the range of 10.5 to $49.6 \mathrm{~cm}$. The maximum catch was between the size groups 21.1-31.0 cm (Fig. 3).

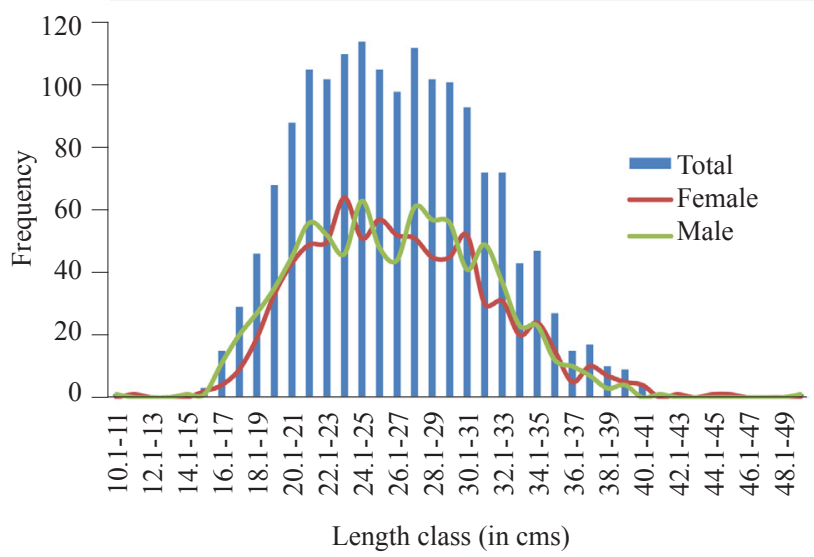

Fig. 3. Length frequency distribution of $L$. inermis from southeastern Arabian Sea during 2017-19

\section{Length-weight relationship}

The maximum total length for males and females were 49.6 and $46 \mathrm{~cm}$ whereas the minimum was 10.5 and $11.8 \mathrm{~cm}$ respectively. The maximum total weight for males and females was 1,140 and 1,432 $\mathrm{g}$ and the minimum was 42 and $39 \mathrm{~g}$ respectively. The regression equations for the length-weight relationships of males and females and sexes pooled were calculated (Table 1).

Growth in both sexes was found to be negative allometric $(b<3)$. The LWR varied significantly between sexes $(\mathrm{p}<0.01)$.

\section{Condition factor $(K)$ and relative condition factor $\left(K_{n}\right)$}

The mean condition factor of $L$. inermis was 1.67 and the monthly mean condition factor is given in Table 2 . Value of $K$ was comparable between the sexes throughout the year except for December when it was 1.56 for males and 1.81 for females respectively. Mean relative condition factor for both male and female L. inermis was equal to 1 which signifies that the condition of the fish is good (Table 3). The $K_{n}$ values for males was high from March to September while that of the females did not show any clear pattern as such. $K_{n}$ values for females were high in January, March, April, August and November. Condition factor for both the sexes was found to be significantly different between months $(p<0.01)$ but was not significantly different $(p<0.01)$ between the sexes.

Sex ratio

A total of 1,722 samples were analysed for determining the sex ratio. It was found to be $1: 1.08$ which is 
Table 1. Length-weight relationship of L. inermis from south-eastern Arabian Sea during 2017-19

\begin{tabular}{|c|c|c|c|c|c|c|c|c|c|c|}
\hline \multirow{2}{*}{ Sex } & \multirow{2}{*}{$\mathrm{N}$} & \multicolumn{4}{|c|}{ Length and weight characteristics } & \multicolumn{3}{|c|}{ Parameters of LWR } & \multirow{2}{*}{$\mathrm{df}$} & \multirow{2}{*}{ Growth $(+/-)$} \\
\hline & & $\mathrm{L}_{\text {mean }}$ & $\pm \mathrm{SD}(\mathrm{cm})$ & $\mathrm{W}_{\text {mean }}$ & $\pm \mathrm{SD}(\mathrm{g})$ & a & $\mathrm{b}$ & $r^{2}$ & & \\
\hline Male & 814 & 26.46 & 4.99 & 321.76 & 167.78 & 0.034805 & 2.760 & 0.944 & 813 & Negative \\
\hline Female & 753 & 26.65 & 5.22 & 343.5 & 189.56 & 0.033574 & 2.782 & 0.940 & 752 & Negative \\
\hline Pooled & 1568 & 26.56 & 5.12 & 332.91 & 180.54 & 0.033979 & 2.773 & 0.942 & 1567 & Negative \\
\hline
\end{tabular}

Table 2. Monthly condition factor $(K)$ of $L$. inermis during 2017-19 from south-eastern Arabian Sea

\begin{tabular}{lll}
\hline \multirow{2}{*}{ Month } & \multicolumn{2}{c}{ Condition factor } \\
\cline { 2 - 3 } & Male & Female \\
\hline January & 1.69 & 1.63 \\
February & 1.56 & 1.6 \\
March & 1.65 & 1.60 \\
April & 1.76 & 1.79 \\
May & 1.70 & 1.65 \\
August & 1.57 & 1.62 \\
September & 1.75 & 1.63 \\
October & 1.65 & 1.78 \\
November & 1.64 & 1.68 \\
December & $1.56^{*}$ & $1.81^{*}$ \\
\hline
\end{tabular}

"Mean condition factor between male and female is significantly different

Table 3. Monthly relative condition factor $\left(K_{n}\right)$ of $L$. inermis from south-eastern Arabian Sea during 2017-19

\begin{tabular}{lll}
\hline \multirow{2}{*}{ Month } & \multicolumn{2}{c}{ Relative condition factor } \\
\cline { 2 - 3 } & Male & Female \\
\hline January & 1.03 & 1.04 \\
February & 0.86 & 0.85 \\
March & $1.10^{*}$ & $1.11^{*}$ \\
April & $1.10^{*}$ & $1.10^{*}$ \\
May & $1.00^{*}$ & 0.97 \\
August & $1.02^{*}$ & $1.14^{*}$ \\
September & $1.04^{*}$ & 0.92 \\
October & 0.87 & 0.89 \\
November & 0.98 & $1.03^{*}$ \\
December & 0.98 & 0.98 \\
\hline
\end{tabular}

"The mean relative condition factor is significantly high during March and April

not significantly different from the hypothetical ratio of $1: 1$. The ratio was unusually high in the post-monsoon months of December and January (1:2 and 1:2.3 respectively). The lowest values were observed in the monsoon months of August and September (1:0.58 and 1:0.42 respectively). Chi-square test revealed that the sex ratio was not significantly different throughout the year except for September, December and January $(p<0.01)$ (Table 4).

\section{Spawning season}

Maturity stages of both the testes and ovaries indicated that this species is a continuous spawner with the highest peaks in February, August and December.
Table 4. Monthly sex ratio and Chi-square test value of $L$. inermis from south-eastern Arabian Sea during 2017-19

\begin{tabular}{lll}
\hline Month & Sex ratio & Chi-Square $\left(\chi^{2}\right)$ \\
\hline January & $1: 2.30^{*}$ & $33.93^{*}$ \\
February & $1: 0.67$ & 6.49 \\
March & $1: 0.97$ & 0.03 \\
April & $1: 1.05$ & 0.08 \\
May & $1: 0.80$ & 1.93 \\
August & $1: 0.58$ & 8.21 \\
September & $1: 0.42$ & $28.80^{*}$ \\
October & $1: 1.29$ & 2.96 \\
November & $1: 0.69$ & 8.07 \\
December & $1: 2.00^{*}$ & 18.33 \\
\hline
\end{tabular}

*Significant $(\mathrm{p}<0.01)$

In May and October there is a sudden dip indicating the presence of inividuals in spent recovering phase. Highest spawning was observed from November to February and in August (Fig. 4).

\section{Gonado-somatic index (GSI)}

In the present study, weight of the ovary and testes varied significantly throughout the year. Highest mean GSI value for ovary was observed in August (8.08) and lowest in May (3.32). Similarly, the highest mean GSI value for testes was observed in August (5.82) and the lowest during May (3.49) (Fig. 5). In all the other months for both male and female the mean GSI value ranged between 4.22 and 5.82 .

Hepatosomatic index (HSI)

The monthly mean HSI value of $L$. inermis did not vary much during the study period. The highest mean HSI

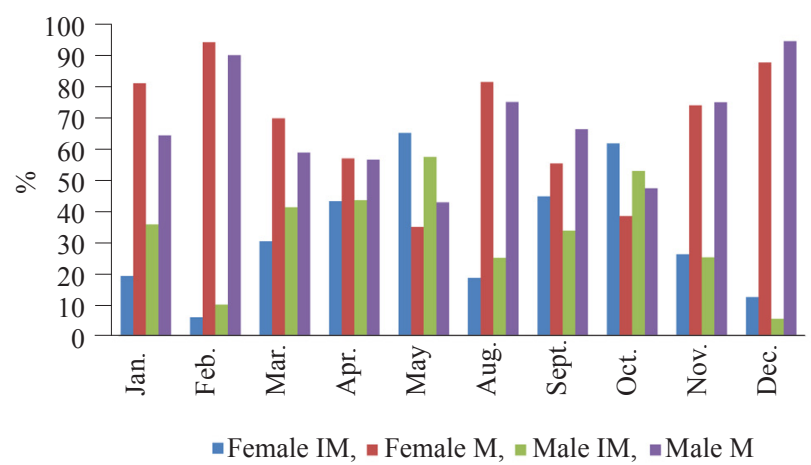

Fig. 4. Maturity stages of $L$ inermis 


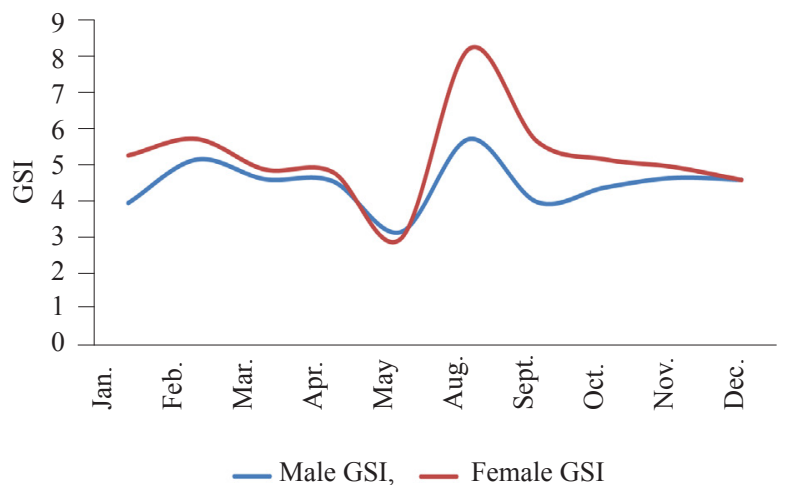

Fig. 5. Mean gonadosomatic index of $L$. inermis

was recorded during May (5.21) and the lowest during August (3.99) (Fig. 6). Throughout all other months, the mean HSI value did not vary much and was in the range 4.38 to 5.09 .

\section{Discussion}

The biology of $L$. inermis is an unexplored area and hence very limited published information is available for comparison. The results of LWR of $L$. inermis were found to be analogous with the works done along the south-west coast of India (Joshi, 2004; Padmavathi et al., 2017; Anju et al., 2019). The $b$ values in their findings were also less than 3 indicating that the growth is negative allometric. L. sceleratus from the Gulf of Suez showed negative allometric growth with $b$ value less than 3 for both sexes (2.9 for males; 2.84 for females and 2.86 for combined sexes) (Sabrah et al., 2006). Along the west coast of India, Naik and Jalihal (1998), studied the LWR of the males and females of $L$. spadiceus and the values were estimated to be 2.61 and 2.49 respectively. Some studies on the LWR of L. inermis has been done in Kerala (Joshi, 2004; Anju et al., 2019), India and our results agree with theirs in the $b$ value being less than 3 . This indicates that the fish grows more in weight compared to its length.

Data pertaining to sex ratio plays a vital role in our understanding of the correlation between individuals, populations and the environment as a whole (Vicentini and Araujo, 2003). The expected or standard sex ratio is $1: 1$ which varies from species to species and also within the same population at various point of time depending upon several factors like reproduction strategy, availability of food, environmental conditions and adaptation to environmental changes. L. inermis was found to have higher number of females during the month of October and males were higher from September to December (Naik and Jalihal, 1998). Sabrah et al. (2006) studied the biology of L. sceleratus including their sex ratio. The results revealed that females were predominant during late spring i.e., from April to June and males were

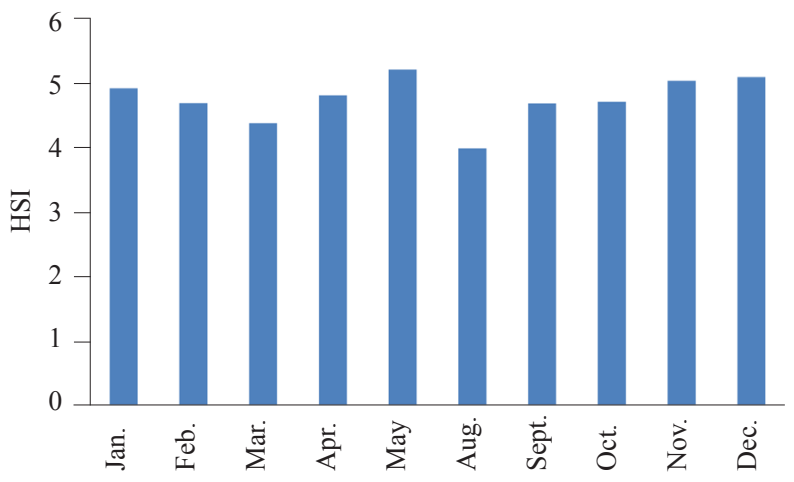

Fig. 6. Mean hepatosomatic index of L. inermis

predominant from February to March. However, in this study we found that the females were predominant from December to January (post-monsoon season) along the south-west coast of India, possibly due to aggregation of females for spawning.

Joshi (2004) concluded that the $K_{n}$ values of both the sexes of $L$. inermis were in synchronisation with their reproductive behaviour. This result has been documented in our study also where the value of the relative condition factor is high in the months of March and April, synchronising with the reproductive activity.

Although the occurrence of mature fishes was observed to be $>30 \%$ throughout the year, the percentage of mature individuals in August and during NovemberFebruary, was high $(<70 \%)$ indicating peak spawning in these months. This finding is unequivocal with the results obtained from the gonadosomatic index study, which indicated high values during these months. This again corroborates the fact that $L$. inermis spawns throughout the year with the peak spawning season during November to February and August. During the south-west monsoon season (June-July), fishing using mechanised vessels is banned along the entire south-west coast and so data could not be collected during those months. As the GSI value drops suddenly in May and September and is at peak during August, it might be possible that the spawning actually commences somewhere in June or July. This result is synchronous with the research findings of Joshi (2004), who found that L. inermis spawned twice a year, during April and October. It was also observed that when the GSI value was the highest, HSI value was lowest i.e. during the month of August indicating that the liver undergoes decrease in weight during reproduction. This may be due to the transfer of energy reserves for gonadal development and maturation (Zin et al., 2011).

This study provides vital information on LWR, condition factor, sex ratio, spawning season, GSI and HSI of $L$. inermis which is an emerging fishery resource 
along the south-eastern Arabian Sea, and bears ecological significance in the trophic network (Mohamed et al., 2013). LWRs showed negative allometry which can be attributed to species specific morphological characteristics or environmental conditions. $K_{n}$ values were mostly above or close to 1 which shows the overall well-being of the resource. Sex ratio was uniform except for two months when the females were predominant and could be attributed to their spawning behaviour. The GSI and HSI values were inversely proportional to each other and the study confirms two spawning peaks for $L$. inermis along this coast viz., November to February and August. The parameters generated in this study will be useful for sustainable management of the fishery resource.

\section{Acknowledgements}

We thank the Director, ICAR-CMFRI, Scientistin-Charge, Mangalore RC of ICAR-CMFRI and Dr. P. U. Zacharia, Head, Demersal Fisheries Division, ICAR-CMFRI and Principal Investigator-NICRA project for their continuous support and guidance. We acknowledge ICAR-National Innovations on Climate Resilient Agriculture (NICRA) for providing financial support for the study. We also thank Mr. G. D. Nataraja for his help during sampling. The help rendered by the fishermen of Mangalore Fishing Harbour is also duly acknowledged.

\section{References}

Anderson, R. O. and Gutreuter, S. J. 1983. Length, weight and associated structural indices. In: Nielsen L. and Johnson D. (Eds.), Fisheries techniques, American Fisheries Society, Bethesda, Maryland, USA, p. 284-300.

Anju, C. V., Dahanukar, N., Sidharthan, A., Ranjeet, K. and Raghavan, R. 2019. Demographics of Lagocephalus inermis in the Arabian Sea unveils complex conservation challenges. J. Fish Biol., 94: 187-190. doi:10.1111/jfb. 13873.

Başusta, A., Başusta, N. and Ozer, E. I. 2013. Length-weight relationship of two puffer fishes, Lagocephalus sceleratus and Lagocephalus spadiceus, from Iskenderun Bay, Northeastern Mediterranean, Turkey. Pak. J. Zool., 45(4): 10471051.

Beyer, J. E. 1987. On length-weight relationships. Part I: Computing the mean weight of the fish of a given length class. Fishbyte, 5: 11-13.

Bilge, G., Filiz, H. and Yapici, S. 2017. Length-weight relationships of four Lessepsian puffer fish species from Mugla coasts of Turkey. Nat. Eng. Sci., 2(3): 36-40. https:// doi.org/10.28978/nesciences.369527.

Bolger, T. and Connolly, P. L. 1989. The selection of suitable indices for the measurement and analysis of fish condition. J. Fish Biol., 34: 171-182. DOI: 10.1111/j.1095-8649.1989. tb03300.x.
Dulcic, J. and Kraljevic, M. 1996. Weight-length relationships for 40 fish species in the eastern Adriatic (Croatian waters). Fish. Res., 28(3): 243-251. https://doi.org/10.1016/01657836(96)00513-9.

Gonçalves, J. M. S., Bentes, L., Lino, P. G., Ribeiro, J., Canario, A. V. M. and Erzini, K. 1997. Weight-length relationships for selected fish species of the small-scale demersal fisheries of the south and south-west coast of Portugal. Fish. Res., 30: 253-256. https://doi.org/10.1111/ j.1467-2979.2006.00206.x.

Joshi, C. O. 2004. Systematics and bionomics of tetraodontids along south west coast of India and inland waters of Kerala, Ph. D. Thesis, Department of Zoology, Christ College, Irinjalakuda, University of Calicut, Kerala, India, 243 pp.

Koops, M. A., Hutchings, J. A. and McIntyre, T. M. 2004 Testing hypotheses about fecundity, body size and maternal condition in fishes. Fish Fish., 5: 120-130. https://doi. org/10.1111/j.1467-2979.2004.00149.x.

Le Cren, E. D. 1951. The length-weight relationship and seasonal cycle in gonadal weight and condition in the perch, Perca fluviatilus. J. Anim. Ecol., 20: 201-219. https:// doi.org/10.2307/1540.

Lenhardt, M., Jaric, I, Cakic, P., Cvijanovic, G., Gacic, Z. and Kolarevic, J. 2009. Seasonal changes in condition, hepatosomatic index and parasitism in starlet (Acipenser ruthenus L.). Turk. J. Vet. Anim. Sci., 33(3): 209-214.

Lovern, J. A. and Wood, H. 1937. Variation in the biochemical composition of herring. J. Mar. Biol. Ass. U. K., 22: 281-293.

Matsuura, K. 2015. Taxonomy and systematics of tetraodontiform fishes: A review focusing primarily on progress in the period from 1980 to 2014. Ichthyol. Res., 62: 72-113. DOI 10.1007/s10228-014-0444-5.

Mohamed, K. S., Sathianandan, T. V., Kripa, V. and Zacharia, P. U. 2013. Puffer fish menace in Kerala: A case of decline in predatory control in the south-eastern Arabian Sea. Curr. Sci., 104(4): 426-429.

Morato, T., Alfonso, P., Lourinho, P., Barreiros, J. P., Santos, R. S. and Nash, R. D. M. 2001. Length-weight relationship for 21 coastal fish species of the Azores, northeastern Atlantic. Fish. Res., 50: 297-302. doi: 10.1016/ S0165-7836(00)00215-0.

Naik, S. D. and Jalihal, D. R. 1998. Biological observations on the puffer fishes of south Konkan coast with special reference to the net-damaging species Lagocephalus spadiceus (Osteichthyes, Tetraodontidae). Indian J. Mar. Sci., 27: 426-432.

Padmavathi, P., Sujatha, K. and Iswarya Deepti V. A. 2017. Studies on length groups and length-weight relationship of puffer fishes (Pisces: Tetraodontidae) in the catches off Vishakhapatnam, India. Indian J. Mar. Sci., 46(05): 972-981.

Parameswaran, S., Selvaraj, C. and Radhakrishnan, S. 1974. Observation on the biology of Labeo gonius (Hamilton) Indian J. Fish., 21: 54-75. 
Ricker, W. E. 1975. Computation and interpretation of biological statistics of fish population, In: Stevenson, J. C., Watson, J., Wigmore, R. H. and Reihart, J. M. (Eds.), Bulletin of the Fisheries Research Board of Canada, No. 191, Department of the Environment, Fisheries and Marine Service, Ottawa, Canada, p.191-382.

Sabrah, M. M., El-Ganainy, A. A. and Zaky, M. A. 2006. Biology and toxicity of the puffer fish Lagocephalus sceleratus (Gmelin, 1789) from the Gulf of Suez. Egyptian J. Aquat. Res., 32(1): 283-297.

Safran, P. 1922. Theoretical analysis of the weight-length relationship in fish juveniles. Mar. Biol., 112(4): 545-551.

Saha, P., Thomas, S., Salian, T. S., Dineshbabu, A. P., Rohit, P. and Nataraja, G. D. 2019. Fishery and GIS based spatio-temporal distribution analysis of smooth blaasop Lagocephalus inermis, in south-eastern Arabian Sea. Turk. J. Fish. Aquat. Sci., 20(4): 267-278.

Simon, K. D. and Mazlan, A. G. 2008. Length-weight relationships of Archer and puffer fish species. Open Fish Sci. J., 1: 19-22. DOI: 10.2174/1874401X00801010019.

Sirisha, R. I. and Rao, P. Y. 2013. Length-weight relationship and growth of the green-rough-back puffer fish Lagocephalus lunaris (Bloch and Schneider, 1801), off Vishakhapatnam, east coast of India. Adv. Appl. Sci. Res., 4(4): 123-128.

Sokal, R. R. and Jamesrohlf, F. 1987. Introduction to biostatistics, $2^{\text {nd }}$ edn. Freeman and Co., New York, USA, 363 pp.

Stratoudakis, Y., Bernal, M., Ganias, K. and Uriarte, A. 2006. The daily egg production method: Recent advances, current applications and future challenges. Fish Fish., 7: 35-37. DOI: 10.1111/j.1467-2979.2006.00206.x.

Thomas, S., Kemparaju, S. and Sampath, G. K. 2009. Puffer fish Lagocephalus inermis, an emerging fishery along
Mangalore coast of Karnataka. Mar. Fish. Inf. Serv. T\&E Ser., 200: 23-24.

Tyler, A. V. and Dunns, R. S. 1976. Ration, growth and measures of somatic and organ condition in relation to meal frequency in winter flounder Pseudopleuronectes americanus with hypotheses regarding population homeostasis. J. Fish. Res. Board Can., 33: 63-75.

Vazzoler, A. E. A. M. 1996. Biology of production of Pisces, Teleosts: Theory and practice. State Univeristy of Maringa, Brazil, 169 pp. (In Portuguese)

Vicentini, R. N. and Araujo, F. G. 2003. Sex ratio and size structure of Micropogonias furnieri (Desmarest, 1823) (Perciformes, Sciaenidae) in Sepetiba Bay, Rio de Janeiro, Brazil. Braz. J. Biol., 63: 559-566.

Welcomme, R. I. 2001. Dynamics of fish populations. In: Inland fisheries, ecology and management. Fishing New Books, Blackwell Science, Oxford, UK, p. 42-69.

Yeldan, H. and Avsar, D. 2000. A preliminary study on the reproduction of the rabbit fish Siganus rivulatus (Forsskal. 1775) in the North-eastern Mediterranean. Turk. J. Zool., 24: $173-182$

Zargar, U. R., Yousuf, A. R., Mushtaq, B. and Jan, D. 2012. Length-weight relationship of the crucian carp, Carassius carassius in relation to water quality, sex and season in some lentic water bodies of Kashmir Himalayas. Turk. J. Fish. Aquat. Sci., 12: 685-691. DOI: 10.4194/1303-2712v12_3_17.

Zin, T., Than, A. A. and Naing, T. T. 2011. Fecundity (F), gonadosomatic Index (GSI), hepatosomatic index (HSI), condition factor (K) and length-weight relationship (LWR) in Channa orientalis Bloch and Schneider, 1801. Univ. Res. J., 4(2): 47-62. 